\title{
EVALUASI PENGGUNAAN ANTIBIOTIK PADA PASIEN PEDIATRI PENYAKIT DIARE DI INSTALASI RAWAT INAP RSUD SULTAN IMANUDDIN PANGKALAN BUN KALIMANTAN TENGAH TAHUN 2018
}

\author{
${ }^{1}$ Firmansyah, ${ }^{2}$ Yogie Irawan \\ ${ }^{1}$ STIKes Borneo Cendekia Medika Pangkalan Bun \\ Email : syahrahmanfirman@gmail.com
}

\begin{abstract}
ABSTRAK
Pendahuluan : Diare merupakan penyebab utama tingginya angka kematian pada anak didunia karena dehidrasi dan kehilangan cairan tubuh, berdasarkan penyebabnya diare dapat dibedakan sebagai diare terkait infeksi dan non-infeksi. Penyebab diare terkait infeksi banyak ditemukan pada anak di bawah usia 5 tahun. Mikroorganisme penyebab diare tidak selalu bakteri. Diare persisten memiliki kecenderungan disebabkan oleh infeksi bakteri. Oleh karena itu, antibiotik dapat digunakan sebagai terapi lini pertama penanganan kasus diare persisten dan bukan pada kasus diare akut anak Ironisnya, pemakaian antibiotik secara tidak rasional pada pasien pediatri penyakit diare masih banyak terjadi di berbagai daerah. Meningkatnya Prevalensi penggunaan antibiotik pada pasien pediatri penyakit diare menuntut adanya ketepatan terapi untuk menekan angka kesakitan. Salah satu aspek yang berkaitan dengan hal tersebut adalah rasionalitas penggunaan antibiotiknya. Tujuan penelitian ini adalah untuk mengetahui gambaran penggunaan antibiotik dan evaluasi rasionalitas penggunaan antibiotik pada pasien pediatri penyakit diare di Instalasi Rawat Inap RSUD Sultan Imanuddin Pangkalan Bun Kalimantan Tengah Tahun 2018.
\end{abstract}

Metode : Penelitian ini merupakan penelitian non eksperimental. Pengumpulan data secara retrospektif dan dianalisis secara deskriptif. Teknik sampling yang digunakan adalah purposive sampling. Diperoleh data sebanyak 74 rekam medik. Penelitian dilakukan dengan mengevaluasi rasionalitas penggunaan antibiotik berdasarkan tepat indikasi, tepat obat, tepat dosis, tepat cara pemberian dan tepat lama pemberian. Data yang didapat dibandingkan dengan Guideline Di Piro Tahun 2017

Hasil : Hasil penelitian menunjukkan bahwa dari 74 pasien, penggunaan antibiotik yang digunakan pada pasien pediatri penyakit diare di Instalasi Rawat Inap RSUD Sultan Imanuddin Pangkalan Bun Kalimantan Tengah Tahun 2018. Adalah Ceftriaxone sebesar $56,75 \%$, Cefotaxime sebesar $32,43 \%$, Cefixime 5,40\%, ciprofloxacine 5,40\%. Evaluasi penggunaan antibiotik pada pasien pediatri penyakit diare berdasarkan Guideline Di Piro Tahun 2017 meliputi tepat indikasi sebesar 100\%, tepat obat sebesar 100\%, tepat dosis sebesar $94,59 \%$, tepat cara pemberian sebesar $100 \%$, dan tepat lama pemberian sebesar $100 \%$

Kesimpulan : Berdasarkan hasil penelitian ini diperoleh bahwa penggunaan antibiotik pada pasien pediatri penyakit diare berpengaruh terhadap rasionalitas antibiotik yaitu tepat indikasi, tepat obat, tepat dosis, tepat cara pemberian, tepat lama pemberian

Kata Kunci : Diare, penggunaan antibiotik, evaluasi rasionalitas, pasien pediatri 


\begin{abstract}
ABSTRAK
Introduction : Diarrhea is the main cause of high mortality rates in children in the world due to dehydration and loss of body fluids. Based on the cause, diarrhea can be distinguished as infection-related diarrhea and non-infection. The causes of infectionrelated diarrhea are common in children under 5 years of age. The microorganisms that cause diarrhea are not always bacteria. Persistent diarrhea has a tendency to be caused by a bacterial infection. Therefore, antibiotics can be used as a first-line therapy for the management of persistent diarrhea cases and not in cases of acute diarrhea in children. Ironically, the irrational use of antibiotics in pediatric patients with diarrheal disease still occurs in many regions. The increasing prevalence of antibiotic use in pediatric patients with diarrheal disease demands the right therapy to reduce morbidity. One aspect related to this is the rationality of using antibiotics. The purpose of this study was to describe the use of antibiotics and evaluate the rationality of antibiotic use in pediatric patients with diarrhea at the Sultan Imanuddin Pangkalan Bun Hospital, Central Kalimantan in 2018.
\end{abstract}

Method : This research is a non experimental research. Datum collection is retrospectively and analyze descriptively. The sampling technique used was purposive sampling. Obtained data as many as 74 medical records. The study was conducted by evaluating the rationality of antibiotic use based on the precise indication, precise drug, precise dose, precise way of administration and the precise duration of giving.

Result: The results showed that out of 74 patients, the use of antibiotics used in pediatric patients with diarrheal disease in the Inpatient Installation of the Sultan Imanuddin Pangkalan Bun Hospital, Central Kalimantan in 2018. These were Ceftriaxone of $56.75 \%$, Cefotaxime of $32.43 \%$, Cefixime $5.40 \%$, ciprofloxacine $5.40 \%$. Evaluation of the use of antibiotics in pediatric patients with diarrheal disease based on the Guideline Di Piro 2017 includes $100 \%$ precise indication, $100 \%$ precise drug, $94.59 \%$ precise dose, $100 \%$ precise method, and $100 \%$ precise duration of giving.

Conclucion : Based on the result of this study, it was found that the use of antibiotics in pediatric patients with diarrhea affects to rasionality of antibiotics, namely precise indication, precise drug, percise dose, percise way of administration, and the precise duration of giving

Keywords: diarrhea, antibiotic use, rationality evaluation, pediatric patients.

PENDAHULUAN

Diare adalah suatu kondisi dimana seseorang buang air besar dengan konsistensinya cair atau lembek, dan frekuensinya 3 kali atau lebih dalam 1 hari. Secara klinis penyebab diare dapat dikelompokkan dalam 6 golongan besar yaitu disebakan oleh bakteri, virus atau infeksi parasit, malabsorpsi, alergi, keracunan, imunodefisiensi dan sebab-sebab lainnya. Penyakit diare sendiri merupakan masalah kesehatan masyarakat dinegara 
berkembang seperti Indonesia, karena morbiditas dan mortilitasnya yang masih tinggi. Diare menjadi salah satu penyebab utama tingginya angka kematian anak di dunia.Pada tahun 2010 secara global distribusi diare sebanyak 716 ribu (10\%) dari 7,6 juta semua kasus kematian anakanak usia $<5$ tahun. Distribusi diare di Asia Tenggara sebanyak 233 ribu (11\%) dari 2,1 juta, pada kasus kematian anak-anak usia $<5$ tahun kemudian dinegara Afrika sebesar 696 juta, sebagian dari dunia sebesar 480 juta sedangkan di Asia Timur dan Pasifik sebesar 435 juta. Pada tahun 2015 lebih dari 1.400 anakanak meninggal setiap hari, atau sekitar 526.000 anak pertahun yang di sebabkan karena diare (WHO, 2015)

Berdasarkan profil kesehatan di Indonesia pada tahun 2015, terjadi 18 kali KLB pada penyakit diare yang tersebar di 11 provinsi, 18 kabupaten/kota dengan jumlah penderita sebanyak 1.213 orang dan kematian 30 orang (CFR 2,47\%). Angka kesakitan nasional tersebut bersumber dari hasil survei morbiditas penyakit diare tahun 2015 yaitu sebesar 214/1.000 penduduk.
Maka dapat diperkirakan jumlah penderita diare di fasilitas kesehatan sebanyak 5.097.247 orang, sedangkan jumlah penderita diare dilaporkan ditangani dibeberapa fasilitas kesehatan sebanyak 4.017.861 orang atau 74,33\% dengan target 100\%. Pada tahun 2016 penderita diare di fasilitas kesehatan meningkat sebesar 6.897 .463 orang dan diare yang ditangani di fasilitas kesehatan sebanyak 2.554.084 orang atau dengan prosentase sebesar 36,9\% (Kemenkes RI, 2016)

Berdasarkan data dari Dinas Kesehatan Pangkalan Bun pada tahun 2018, diketahui bahwa penyakit diare masuk dalam 10 kategori penyakit terbesar yang ada di daerah Pangkalan Bun, Kalimantan Tengah. Kasus penyakit diare pada tahun 2018 yang terjadi di Pangkalan Bun dengan jumlah total 2840, data tersebut diperoleh dari 4 puskesmas di kotawaringin barat yaitu dari puskesmas madurejo, puskesmas mendawai, puskesmas pangkalan lada dan puskesmas pandu sanjaya. Sedangan di RSUD Sultan Imanuddin sendiri penyakit diare menempati posisi ke 4 dari 10 penyakit terbesar yang ada RSUD 
Sultan Imanuddin dengan jumlah pasien 665 orang, pasien perempuan berjumlah 300 orang dan laki-laki 365, dari angka tersebut jumlah pasien keluar dengan sehat sebesar 650 pasien, sedangkan jumlah pasien yang keluar dengan kondisi meninggal sebanyak 15 pasien (Dinkes, 2018).

Pada dasarnya diare dapat berbahaya jika disertai dengan terjadi dehidrasi. Dehidrasi yang dialami, mulai dari dehidrasi ringan hingga dehidrasi berat, bahkan ada yang dapat mengakibatkan kematian. Berdasarkan WHO pada tahun 2015 lebih dari 10 juta anak yang berusia kurang dari 5 tahun diperkirakan meninggal setiap tahunnya, atau sebesar $20 \%$ anak meninggal diakibatkan penyakit diare, dikarenakan diare yang berlangsung selama beberapa hari sehingga tubuh kehilangan banyak cairan yang penting seperti air dan garam yang diperlukan untuk kelansungan hidup, kebanyakan anak yang meninggal karena mengalami dehidrasi berat.Untuk menurunkan kematian karena diare perlu adanya tata laksana yang cepat dan tepat. Penatalaksanaan penyakit diare akut tersebut seperti penggantian cairan dan elektrolit, serta dapat menggunakan obat antidiare untuk penyakit diare akut non infeksi, sedangkan pada penyakit diare akut infeksi dapat ditambahkan dengan obat antibiotik. Antibiotik yang dapat digunakan pada penyakit diare akut infeksi haruslah rasional (Fithria dan Di'fain, 2015).

Maka dari itu perlu adanya evaluasi mengenai penggunaan obat antibiotik yang bertujuan untuk memahami jenis dan jumlah antibiotik yang diberikan pada pasien diare. Dari berbagai studi telah menemukan bahwa sekitar 40-62\% antibiotik dipakai secara tidak tepat, $30-80 \%$ kualitas penggunaan obat antibiotik diberbagai rumah sakit ditemukan tidak berdasarkan pada indikasi (Permenkes, 2014). Berdasarkan standar IDAI (Ikatan Dokter Anak Indonesia) obat antibiotik yang digunakan pada terapi penyakit diare karena infeksi dan parasit yang terlibat pada WHO antara lain adalah Metronidazole untuk terapi amoebiasis dan giardiasis, Cefriakson, Ciprofloxacin dan Pivmecillinam digunakan untuk terapi karena infeksi Shigella 
dysentery, sedangkan eritromisin dan tetrasiklin digunakan pada terapi kolera (Meila, 2016).

Berdasarkan penyebabnya penyakit diare dapat dibedakan sebagai diare terkait infeksi dan noninfeksi. Penyebab diare terkait infeksi banyak ditemukan pada anakanak di bawah usia 5 tahun. Mikroorganisme penyebab diare tidak selalu bakteri, Diare persisten memiliki kecenderungan disebabkan oleh infeksi bakteri. Oleh karena itu, antibiotik dapat digunakan sebagai terapi lini pertama penanganan kasus diare persisten dan bukan pada kasus diare akut anak. Evaluasi Penggunaan antibiotik yang tidak rasional dapat menyebabkan resistensi yaitu bakteri akan memberikan perlawanan terhadap antibiotik. Dalam memilih antibiotik untuk pasien anak, diperlukan pemahaman farmakologi klinis obat yang akan dipergunakan. Hal lain yang perlu diperhatikan dalam penggunaan antibiotik adalah dosis, cara pemberian, dan indikasi pengobatan (Munaf, 2015).

Meningkatnya pravelensi pemakaian obat antibiotik yang tidak rasional pada pasien diare merupakan penyebab timbulnya resistensi, data mengenai timbulnya resistensi sebesar 30-63\% Dampak lain dari penggunaan obat antibiotik tidak rasional berupa biaya pengobatan pasien yang meningkat. Oleh karenanya maka, penggunaan obat antibiotik yang tidak rasional diharapkan dapat memberikan dampak positif bagi pasien, antara lain yaitu mengurangi morbiditas, mortalitas, kerugian materi atau ekonomi, dan dapat mengurangi angka kejadian resistensi bakteri terhadap antibiotik (Febiana, 2015)

Berdasarkan uraian latar belakang tersebut dan tingginya angka kejadian diare di RSUD Sultan Imanuddin Pangkalan Bun tahun 2018 yaitu menempati peringkat ke 4 dari 10 besar peringkat penyakit yang ada di rumah sakit, maka peneliti merasa perlu adanya penelitian yang berkaitan dengan rasionalitas penggunaan antibiotik pada pasien pediatri penyakit diare Instalasi Rawat Inap di RSUD Sultan Imanuddin Pangkalan Bun.

\section{METODE PENELITIAN}

Penelitian ini menggunakan metode deskriptif, menggunakan 
desain penelitian Teknik purposive sampling

\section{Populasi dan sampel}

Populasi dalam penelitian adalah seluruh rekam medik pasien penyakit diare di instalasi rawat inap RSUD Sultan Imanuddin Pangkalan Bun 2018, sampel yang digunakan data rekam medik pasien pediatrik dengan usia 1-11 tahun penyakit diare sebanyak 287 orang.

\section{Kriteria inklusi dan ekslusi}

Kriteria inklusi dalam penelitian ini adalah pasien pediatrik penyakit diare umur 1-11 tahun dan pernah berobat di RSUD Sultan Imanuddin Pangkalan Bun. Sedangkan kriteria ekslusi adalah pasien pediatrik penyakit diare pulang paksa dan pasien pediatrik yang meninggal dalam perawatan.

\section{Pengambilan data}

Sumber data dalam penelitian ini yaitu data sekunder yang diperoleh secara tidak langsung dari data lampau pasien pediatrik penyakit diare, pada penelitian ini diawali dengan merancang proposal penelitian, lalu diajukan permohonan penelitian ke RSUD Sultan Imanuddin Pangkalan Bun, setelah disetujui dilakukan penelitian dengan mengelola rekam medik pasien pediatri penyakit diare selama tahun 2018. Kemudian diambil sampel rekam medik dengan menggunakan Teknik sampling, kemudian diolah sesuai dengan tujuan penelitian, dengan menganalisis gambaran berdasarkan tujuan penelitian. Hasil analisis disajikan secara deskriptif dalam bentuk presentase diagram/ tabel berdasarkan tujuan penelitian pasien pedriatri. Diare diinstalasi rawat inap RSUD Sultan IManudin Pangkalan Bun.

\section{Analisa data}

Hasil penelitian ini terdiri dari data deskritf. Pasien digunakan untuk mendapatkan presentase jenis kelamindan usia, data terapi obat digunakan untuk memperoleh gambaran pola penggunaan kerasionalan obat pada pasien dengan diagnose penyakit diare meliputi jenis obat, golongan obat, bentuk sediaan dan regimen dosis, sedangkan kondisi pasien digunakan untuk pasien pediatri penyakit diare. Data- data penelitian tersebut 
dianalisis mengikuti rancangan deskritif non- analitik kemudian diolah dengan program Microsoft Exsel dan disajikan dalam bentuk presentase, nilai rata- rata, tabel dan diagram.

\section{HASIL DAN PEMBAHASAN}

\subsection{Karakteristik Pasien}

Data rekam medik yang diperoleh dari bagian instalasi rekam medik RSUD Sultan Imanudin Pangkalan Bun diperoleh dari data keseluruhan pasien pediatri penyakit diare dengan jumlah populasi 287 pasien dan diperoleh 74 sampel pasien pediatri penyakt diare yang memenuhi kriteria inklusi sebagai bahan penelitian yang mempunyai data rekam medik lengkap.

\subsubsection{Pasien Diare Berdasarkan Jenis Kelamin}

\footnotetext{
Pengelompokan pasien berdasarkan jeis kelamin dilakukan untuk memenuhi jenis kelamin mana yang paling banyak terjadi pada kasus penyakit diare pada pasien pediatri dapat dilihat pada grafik berikut:
}

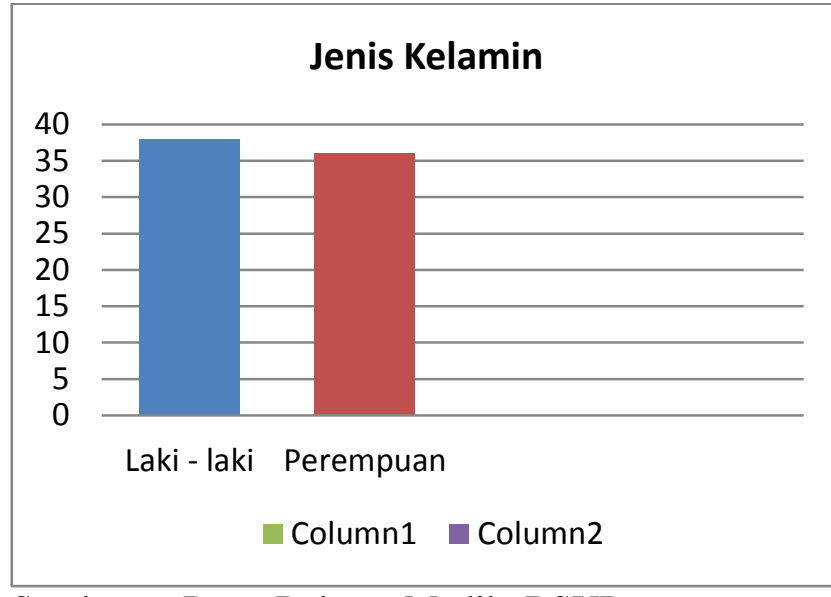

Sumber : Data Rekam Medik RSUD Sultan Imanuddin 2018 yang telah diolah

\subsubsection{Pasien Diare Berdasarkan} usia.

$$
\text { Pengelompokan pasien }
$$
berdasarkan usia bertujuan untuk mengetahui rentang usia berapa pasien pediatri diare yang menggunakan antibiotic sebagai terapi pengobatan, dapat dilihat pada tabel berikut:

\begin{tabular}{|c|c|c|c|}
\hline No & $\begin{array}{l}\text { Kelompok } \\
\text { Usia }\end{array}$ & Jumlah & Persentase \\
\hline 1 & $1-4$ & 57 & $77,02 \%$ \\
\hline 2 & $5-8$ & 9 & $12,16 \%$ \\
\hline 3 & $9-11$ & 8 & $10,81 \%$ \\
\hline & Total & 74 & $100 \%$ \\
\hline
\end{tabular}

Sumber : Data Rekam Medik RSUD

Sultan Imanuddin 2018 yang telah diolah. 


\subsubsection{Pasien Diare Berdasarkan Berat Badan}

Pengelompokan pasien berdasarkan berat badan dilakukan untuk mengetahui banyaknya pasien pediatri penyakit diare yang menggunakan obat antidiare di instalasi rawat inap RSUD Sultan Imanudin tahun 2018.

\section{Grafik 5.3 Pasien Diare} berdasarkan Berat Badan



Sumber : Data Rekam Medik RSUD Sultan Imanuddin 2018 yang telah diolah

\subsubsection{Pasien Diare Berdasarkan} Jenis Penyakit Diare

Pengelompokan pasien berdasarkan jenis penyakit diare dilakukan untuk mengetahui berapa banyak pasien diare ringan dan pasien diare berat yang ada di instalasi rawat inap RSUD Sultan Imanuddin tahun 2018.

\subsubsection{Pasien Diare Berdasarkan Jenis} Penyakit Diare

Sumber : Data Rekam Medik RSUD

Sultan Imanuddin 2018

\begin{tabular}{rlcc}
\hline No & Jenis diare & Jumlah & Persentase \\
\hline 1 & Diare ringsn & 74 & $100 \%$ \\
2 & Diare berat & 0 & $0 \%$ \\
\hline \multicolumn{2}{c}{ Total } & 74 & $100 \%$ \\
\hline & & &
\end{tabular}

Sumber : Data Rekam Medik RSUD

Sultan Imanuddin 2018

\subsection{Kesesuaian Penggunaan Obat} Antibiotik

Kesesuaian dari penggunaan obat menjadi salah satu faktor yang paling penting jika ingin mencapai keberhasilan dalam terapi, diantaranya meliputi kesesuaian penggunaan dari jenis dan golongan obat serta dosis yang perlu untuk diperhatikan

\subsubsection{Jenis Dan Golongan}

\section{Antibiotik}

Pada data hasil penelitian yang menunjukkan penggunaan jenis dan golongan obat antibiotik pada pasien pediatri penyakit diare di Instalasi Rawat Inap RSUD Sultan Imanuddin 
Pangkalan Bun Periode JanuariDesember Periode 2018.

Penggunaan antibiotik yang digunakan pada pasien pediatri penyakit diare terdapat 2 golongan obat antibiotik, yaitu golongan antibiotik sefalosporin sebanyak 70 kasus $(94,58 \%)$ dan Quinolone sebanyak 4 kasus $(5,40 \%)$. Jenis antibiotika yang digunakan pada golongan sefalosporin diantaranya ada ceftriaxone sebanyak 42 kasus $(56,75 \%)$, cefotaxime 24 kasus $(32,43 \%)$, cefixime 4 kasus $(5,40 \%)$, dan golongan quinolone yang digunakan adalah ciprofloxacin 4 kasus (5,40\%). Pada hasil diatas menunjukan bahwa antibiotik paling banyak digunakan yaitu ceftriaxone.

\subsubsection{Dosis Antibiotik}

Pada data hasil dari penelitian yang menunjukkan dosis antibiotik yang digunakan pada pasien pediatri penyakit diare.

Dosis merupakan suatu takaran atau ukuran dari pemberian suatu obat kepada pasien. Dosis sangat berpengaruh dalam terapi penyembuhan pasien tersebut. Hal ini didasarkan bila ukuran dosis yang digunakan tidak sesuai atau tidak tepat maka efek terapi yang diberikan kepada pasien tidak akan terwujud disebabkan akibat dari takaran pemberian dosis yang tidak tepat.

\subsection{Distribusi Penggunaan Obat Antibiotik Pada Pasien Diare}

Berdasarkan penggunaan antibiotik pada pasien pediatri penyakit diare diketahui bahwa jenis antibiotik yang digunakan pada pasien pediatri penyakit diare di instalasi rawat inap RSUD Sultan Imanuddin Pangkalan Bun selama periode Januari-Desember 2018 ada 4 jenis antibiotik yang terdistribusi dalam 2 golongan antibiotik. Evaluasi penggunaan antibiotik untuk pasien pediatri penyakit diare yang akan dibahas berdasarkan jenis antibiotic.

\subsubsection{Ceftriaxone}

Ceftriaxon merupakan antibiotik golongan sefalosporin generasi-III yang aktivitasnya kurang aktif terhadap kokus gram-positif dibandingkan generasi-I, tapi lebih aktif terhadap enterobacteriacce, termasuk strain yang memproduksi betalaktamase. Jumlah pasien yang menerima terapi ceftriaxone 
sebanyak 42 pasien $(52,75 \%)$, yaitu untuk 1-7 hari (Simadibrata et dimana ceftriaxone menjadi al, 2014).

antibiotik pertama yang paling banyak digunakan di instalasi rawat inap RSUD Sultan Imanuddin Pangkalan Bun selama periode Januari-Desember 2018, semua pasien yang berjumlah 49 pasien sudah menerima dosis sesuai dengan literatur Longe Di Piro 2017, dan durasi pemberian obat sesuai dengan jenis pasien pediatri penyakit diare yaitu untuk 1-7 hari (Ghinorawa, 2015).

\subsubsection{Cefotaxime}

Pada data hasil penelitian yang menunjukkan penggunaan antibiotik cefotaxime pada pasien pediatri penyakit diare. Pasien yang menerima terapi antibiotic cefotaxime sebanyak 24 pasien $(32,43 \%)$. Cefotaxime menjadi antibiotik kedua yang banyak dipilih di instalasi rawat inap RSUD Sultan Imanuddin Pangkalan Bun selama periode Januari-Desember 2018. Semua pasien yang berjumlah 24 pasien sudah menerima dosis sesuai dengan literatur guideline Longe $D i$ Piro 2017, dan dengan durasi pemberian obat yang sesuai dengan jenis penyakit pediatri penyakit diare

\subsubsection{Ciprofloxacin}

Pada data hasil penelitian yang menunjukkan penggunaan antibiotik ciprofloxacin pada pasien pediatri penyakit diare di instalasi rawat RSUD Sultan Imanuddin Pangkalan Bun periode Januari-Desember 2018. Ciprofloxacin merupakan antibiotik yang mempengaruhi sintesis atau metabolisme asam nukleat biasanya digunakan untuk infeksi yang disebabkan shigella, E coli, salmonella, haemophilus, Moraxella catarrhalis serta Enterobacteriaceae dan p. aeruginosa, ciprofloxacin hanya memiliki aktivitas sedang melawan bakteri gram positif seperti streptococcus pneumoniae dan enterococcus faecalis, ini aktif melawan klamidia dan beberapa mikobakteri. Jumlah pasien yang menerima terapi ciprofloxacin sebanyak 4 pasien atau $(5,40 \%)$, yang digunakan di instalasi rawat inap RSUD Sultan Imanuddin Pangkalan Bun selama periode Januari-Desember 2018. Semua pasien yang berjumlah 4 pasien sudah menerima dosis sesuai dengan literatur guideline Longe Di Piro 
2017, dan dengan durasi pemberian obat yang sesuai dengan pasien pediatri penyakit diare yaitu 3-7 hari. Berdasarkan The Pediatric Infectious Disease Journal Pemberian dosis normal obat antibiotik ciprofloxacin pada anak adalah $10 \mathrm{mg} / \mathrm{kgbb}$ diberikan tiap 8 jam sehari (Kearns JA, 2010). Penggunaan antibiotik golongan ciprofloxacine hanya sebesar $10 \%$ didasarkan efek samping arthropathy yang dapat mempengaruhi tumbuh kembang anak (Aprilia, 2016).

\subsubsection{Cefixime}

Cefixime merupakan antibiotic golongan sefalosporin generasi ketiga, yang mempunyai aktifitas antimikroba terhadap kuman gram positif maupun negatif termasuk enterobacteria pada pemberian secara oral, hampir 50\% segera mencapai konsentrasi bakterisidal dan menembus jaringan dengan baik. Berdasarkan sifatnya cefixime tersebut dapat mengobati pasien pediatri penyakit diare (Dian, 2015).

\subsection{Evaluasi Rasionalitas} Penggunaan Antibiotik

Evaluasi rasionalitas pengunaan antibiotik dilakukan terhadap 74 pasien, dari data rekam medik pasien pediatri penyakit diare yang telah menjalani perawatan di Instalasi Rawat RSUD Sultan Imanuddin Pangkalan Bun selama periode Januari-Desember 2018. Evaluasi rasionalitas penggunaan antibiotik dilakukan dengan beberapa kriteria kerasionalan, yaitu tepat indikasi, tepat obat, tepat dosis, tepat rute pemberian, tepat durasi pemberian (Kemenkes RI, 2011).

\subsubsection{Tepat Indikasi}

Ketepatan indikasi pada penggunaan obat antibiotik pada pasien diare dapat dilihat dari ketepatan memutuskan pemberian obat yang sepenuhnya berdasarkan alasan medis dan terapi farmakologi yang benar-benar diperlukan. Dikatakan tepat indikasi apabila suatu obat diberikan dengan indikasi yang sesuai dengan gejala penyakit yang diderita pasien tersebut. Evaluasi ketepatan indikasi dapat dilihat dari bab cair lebih dari 3 kali disertai darah atau buih sehingga penggunaan obat antibiotik pada pasien diare sesuai dengan diagnosa penyakit diare (Adriana, 2018).

Berdasarkan penelitian yang telah dilakukan terhadap 74 data 
rekam medik pasien pediatri penyakit diare di Instalasi Rawat Inap RSUD Sultan Imanuddin Pangkalan Bun periode Januari-Desember 2018. Didapatkan nilai dari ketepatan pemilihan obat antibiotik pada pasien diare berdasarkan tepat indikasinya yaitu mencapai mencapai $100 \%$. Penggunaan obat antibiotik pada pasien diare dikategorikan tepat indikasi karena pemberian obat antibiotik golongan selafosporin generasi III, seperti cefotaxime dan ceftriaxone kepada pasien diare yang terinfeksi bakteri shigella yang diketahui dari pemeriksaan klinis dari laboratorium (Amin, 2015).

\subsubsection{Tepat Obat}

Pemberian obat dikatakan tepat apabila jenis obat yang dipilih berdasarkan pertimbangan manfaat dan resiko karena efek obat terkadang tidak sama bagi setiap individu, pengobatan penyakit diare bertujuan untuk mengurangi morbiditas dan mortalitas yang berhubungan dengan faktor resiko penyakit di sistem pencernaan. Evaluasi ketepatan obat dapat dinilai berdasarkan kesesuaian pemilihan terapi tunggal maupun kombinasi dengan mempertimbangkan diagnosis yang tertulis dalam rekam medik dan dibandingkan dengan standar guideline longe de piro 2017 (Mansoer, 2015).

Pada penelitian ini diketahui bahwa dari 74 rekam medik pasien diare di instalasi rawat inap RSUD Sultan Imanuddin Pangkalan Bun periode januari-desember 2018. Didapatkan nilai dari ketepat pemilihan obat antibiotik pasien diare berdasarkan pada tepat obat $100 \%$. Penggunaan obat antibiotik pada pasien pediatri penyakit diare diketegorikan tepat obat karena obat diberikan selafosporin generasi III, seperti cefotaxime dan ceftriaxone kepada pasien diare yang terinfeksi bakteri shigella yang diketahui dari pemeriksaan klinis dari hasil laboratorium (Amin, 2015).

\subsubsection{Tepat Dosis}

Tepat dosis adalah salah satu yang sangat penting untuk menentukan efikasi dari obat, jika dosis suatu obat terlalu tinggi terutama obat yang mempunyai rentang terapi sempit, akan sangat beresiko menimbulkan efek samping, namun jika pemberian dosis obat 
diberikan dibawah rentang terapi, maka tidak menjamin terapi yang diberikan akan tercapai (Kemenkes, 2014). Berdasarkan The Pediatric Infectious Disease Journal Pemberian dosis normal obat antibiotik ciprofloxacin pada anak adalah $10 \mathrm{mg} / \mathrm{kgbb}$ diberikan tiap 8 jam sehari (Kearns JA, 2010). Pada pasien diare dikatakan tepat dosis apabila obat antibiotik penyakit diare berada pada rentang dosis minimal dan dosis perhari yang dianjurkan dalam guideline Longe Di Piro 2017 (Narindrani et al, 2011).

Berdasarkan penelitian yang telah dilakukan terhadap 74 data rekam medik pasien pediatri penyakit diare di instalasi rawat inap RSUD Sultan Imanuddin Pangkalan Bun periode Januari-Desember 2018. Didapatkan nilai dari ketepatan pemilihan obat pasien penyakit diare berdasarkan tepat obat yaitu mencapai 94,59\%. Sedangkan yang mengalami ketidaktepatan dosis sebanyak 5,40\%. Hasil persentasi tersebut sesuai dengan Guideline Di Piro 2017. Ketepatan dosis yaitu ketepatan perhitungan dosis tunggal antibiotik yang digunakan, ketidaktepatan dosis berada pada kasus pasien no 63, 64, 65, 70 yang dimana masing-masing pasien tersebut mendapatkan dosis $2 \times 50$ mg selama 4 hari. Dosis antibiotik ciprofloxacine yang diberikan lebih besar (overdose) atau hasil perhitungan dosis yang diberikan melebihi range dosis pada literatur sesuai Guideline Di Piro 2017. Berdasarkan data tersebut sama dengan Penelitian yang dilakukan Rizqiani (2016) tentang Evaluasi penggunaan antibiotik untuk penyakit diare pada pasien anak di Instalasi Rawat Inap RSI Sultan Agung Semarang tahun 2015, menunjukkan bahwa hasil perbandingan dosis terapi antibiotik perberat badan berdasarkan Drug Information Handbook (2015) maka didapatkan hasil penelitian antibiotik yang tepat dosis sebanyak $87,3 \%$ dan yang tidak tepat dosis sebanyak 12,7\% (Rizqiana, 2016).

\subsubsection{Tepat Rute atau Cara Pemberian}

Tepat cara pemberian obat adalah apabila pemberian sesuai dengan cara pemberian obat seperti melalui intravena atau oral yang tepat sesuai kondisi pasien penyakit diare. Ketepatan rute pemberian 
dapat dinilai berdasarkan kesesuain pasien menerima pemberian obat berdasarkan rute pemberiannya sesuai dengan cara pemakaiannya pada lebel petunjuk penggunaan obat (Amin, 2015).

\section{Tepat Durasi atau Lama}

\section{Pemberian}

Tepat durasi pemberian obat adalah apabila kesesuaian pemberian atau durasi penggunaan obat dalam tiap hari pengobatan, sesuai dengan cara pemberian obat berdasarkan farmakokinetiknya seperti 4 jam, 6 jam atau 12 jam jika obatnya diberikan habis dalam tubuh pada 8 jam maka obat yang diberikan sebaiknya 3 kali sehari. Ketepatan durasi pemberian dapat dinilai berdasarkan kesesuain pasien menerima pemberian obat berdasarkan durasi penggunaan obat pada pasien penyakit diare, kesesuaian durasi penggunaan obat tersebut sesuai guideline longe de piro 2017 (Amin, 2015).

\subsection{Outcome Klinis Efektivitas Antibiotik}

Data hasil penelitian yang diperoleh dianalisis secara deskriptif dalam bentuk tabel untuk mengetahui seberapa efektif penggunaan antibiotik pada pasien pediatri penyakit diare di Instalasi Rawat Inap RSUD Sultan Imanuddin Pangkalan Bun Tahun 2018 sesuai Guideline World Gastroenterology Organisation (WGO, 2014).

Berdasarkan outcome klinis efektivitas penggunaan antibiotik dari peneltian ini bisa di lihat dari LOS, dan Hasil lab yang di ambil dari data rekam medik pasien pediatri penyakit diare di instalasi rawat inap RSUD Sultan Imanuddin Pangkalan Bun 2018 berupa hasil laboratorium yang dapat kita tinjau sebagai dasar efektivitas antibiotik, dapat dilihat dari data peningkatan hasil leukosit yang dimana merupakan salah satu indikator untuk melihat seberapa efektifnya penggunaan antibiotik yang diberikan pada pasien pediatri penyakit diare.

\subsubsection{Pasien Diare Berdasarkan}

\section{Lama Rawat Inap}

Pengelompokan pasien berdasarkan lama rawat inap bertujuan untuk mengetahui berapa lama rata-rata rawat inap tiap pasien pediatri penyakit diare di Instalasi Rawat Inap RSUD Sultan Imanuddin 
Pangkalan Bun 2018. Lama rawat inap dengan outcome klinik membaik pada pasien pediatri penyakit diare adalah waktu dimana pasien masuk rumah sakit sampai keluar rumah sakit dengan dinyatakan sembuh atau membaik oleh dokter. Lama dirawat termasuk ke dalam variabel dengan lama rawat inap >3 hari untuk memonitoring keadaan pasien yang mengalami perbaikan atau sembuh. Kasus diare terinfeksi dapat sembuh $<3$ hari tanpa pemberian antibiotik, sehingga apabila pasien anak diare akut yang lama rawat inap $<3$ hari tidak ada perbaikan kondisi klinis atau belum sembuh dan masih adanya bukti feses yang terinfeksi dengan ditandai feses berlendir dan berdarah maka seharusnya diberikan terapi antibiotik (Sarwono, 2017).

\subsubsection{Pasien Diare Berdasarkan}

\section{Hasil Laboratorium}

Pengelompokan pasien diare berdasarkan hasil lab dari pengobatan pasien diare bertujuan untuk mengetahui efektifnya penggunaan antibiotik pada pasien diare anak di Instalasi Rawat Inap RSUD Sultan Imanuddin Pangkalan Bun Tahun 2018, yang dilihat dari leukosit pada hasil lab yang dilampirkan pada riwayat pengobatan pasien pediatri penyakit diare.

Pengelompokan pasien diare berdasarkan hasil lab dari pengobatan pasien diare bertujuan untuk mengetahui seberapa banyak efektifnya penggunaan antibiotik pada pasien diare anak di Instalasi Rawat Inap RSUD Sultan Imanuddin Pangkalan Bun Tahun 2018, yang dilihat dari standar manusia normal leukositnya berkisar 5000-9000 uL, pada tabel diatas menunjukan seberapa banyak pasien pediatri penyakti diare yang penggunaan antibiotiknya efektif ada pada nomor 6-15 pada tabel tersebut, dikarenakan pada table dengan nomor 6-15 hasil laboratorium menunjukkan kisaran angka diatas standar normal leukosit manusia yang berkisar 5000-9000 uL (Maghfirah, 2016).

\subsection{Kelemahan Penelitian}

Pada penelitian ini terdapat beberapa kelemahan yaitu:

1. Peneliti tidak melihat langsung intensitas atau frekuensi dari gejala yang dialami oleh pasien pediatri penyakit diare di Instalasi Rawat Inap RSUD Sultan 
Imanuddin Pangkalan Bun 2018

karena data diambil secara retrospektif.

2. Peneliti tidak dapat melihat peresepan obat yang dibawa pulang oleh pasien, karena peneliti hanya menelihat rekam medik rawat inap pasien. Perlunya wawancara dengan Dokter atau tenaga medis lain untuk mengetahui alasan pemilihan penggunaan antibiotik pada pasien pediatri penyakit diare di Instalasi Rawat Inap RSUD Sultan Imanuddin Pangkalan Bun Tahun 2018.

\section{BAB VI}

KESIMPULAN DAN SARAN

\subsection{Kesimpulan}

Berdasarkan hasil penelitian yang dilakukan mengenai "Evaluasi Penggunaan

Antibiotik Pada Pasien Pediatri Penyakit Diare Di Instalasi Rawat Inap RSUD Sultan Imanuddin Pangkalan Bun Kalimantan Tengah Tahun 2018”, dapat disimpulkan sebagai berikut:

1. Profil penggunaan antibiotik yang digunakan pada pasien pediatri penyakit diare di Instalasi Rawat Inap RSUD Sultan Imanuddin Pangkalan Bun Tahun 2018 adalah Ceftriaxone sebesar $56,75 \%$, Cefotaxime sebesar $32,43 \%$, Cefixime sebesar $5,40 \%$, dan Ciprofloxacine $5,40 \%$

2. Penggunaan antibiotik pada pasien pediatri penyakit diare di Instalasi Rawat Inap RSUD Sultan Imanuddin Pangkalan Bun Tahun 2018 berdasarkan guideline de piro 2017 $100 \%$ dan meliputi tepat indikasi sebesar 100\%, tepat obat sebesar 100\%, tepat dosis sebesar 94,59\%, tepat cara pemberian sebesar $100 \%$ dan tepat lama pemberian sebesar $100 \%$.

\subsection{Saran}

Berdasarkan hasil penelitian ini, maka dapat disarankan sebagai berikut :

1. Bagi Istitusi Rumah Sakit, diharapkan lebih meningkatkan pemantauan terhadap kelengkapan 
rekam medis pasien, penulisan yang lebih jelas demi mempermudah mengetahui riwayat penyakit, pengobatan pasien dan sehingga dapat digunakan sebagai bahan penelitian berikutnya serta perlu adanya standart pelayanan medis (SPM) dalam pengobatan pasien pediatri.

2. Bagi peneliti selanjutnya, diharapkan adanya penelitian lebih lanjut di rumah sakit lain untuk mendapat gambaran kerasionalan pengobatan pada kasus yang sama dan perlu dilakukan penelitian Drug Related Problem dengan data restrospektif mengenai pengobatan pasien pediatri penyakit diare.

\section{DAFTAR PUSTAKA}

Amin LZ. 2015. Tatalaksana Diare Akut. Continuing Medical Education. Jakarta: halaman: 504-508.

Amin, 2015, Tata Laksana Diare Akut, Jurnal CDK/230, Vol 42 No. 7, Jakarta

American academy of pediatric. 2014. A Guide for Health Professional. Illinois. USA
Dinas Kesehatan. 2018. Profil

Kesehatan Provinsi

Kalimantan Tengah Tahun

2018. Pangkalan Bun : Dinas

Kesehatan kotawaringin barat

Depkes, R. I., 2015. Pedoman Pemberantasan Penyakit Diare. Jakarta: Ditjen PPM dan PL.

Febiana T. 2015. Kajian Rasionalitas Penggunaan Antibiotik di Bangsal Anak RSUP Dr. Kariadi Semarang Periode Agustus-Desember 2011 [Skripsi]. Semarang: Universitas Diponegoro.

Fithria RF, Di'fain AR. 2015. Rasionalitas Terapi Antibiotik Pada Pasien Diare Akut Anak Usia 1-4 Tahun Di Rumah Sakit Banyumanik Semarang Tahun 2013. Journal Pharmacy, Vol.12 No. 02 Desember 2015, ISSN 16933591

Katzung BG. 2014. Farmakologi Dasar dan Klinik Buku 3 Edisi 8. Penerbit Salemba Medika. Hlm 37 - 41 .

Katzung BG. 2014. Basic and clinical pharmakology. 10th edition. Mc-Graw-Hill. USA. pp. 1007-1012.

Kementerian Kesehatan Republik Indonesia. (2016). Profil kesehatan di Indonesia tahun 
2015. Jakarta: Kementerian

Kesehatan Republik Indonesia.

Kementerian Kesehatan RI. 2010. Undang-Undang Republik

Indonesia Nomor 44 Tahun 2010 tentang Rumah Sakit. Jakarta.

Kementerian Kesehatan Republik Indonesia. 2014. Situasi Diare di Indonesia. Buletin Jendela Data dan Informasi Kemenkes volume 2. Jakarta, Halaman:1

Kementerian Kesehatan Republik Indonesia. 2014. Modul penggunaan obat rasional (Kurikulum Pelatihan Penggunaan Obat Rasional). Jakarta, Halaman : 3-8.

Kementrian Kesehatan Republik Indonesia. 2011. Panduan Sosialisasi Tatalaksana Diare pada Balita. Dirjen Pengendalian Penyakit dan Penyehatan Lingkungan. Jakarta.

Kementrian Kesehatan Republik Indonesia. 2011. Pedoman Pelayanan Kefarmasian Untuk Terapi Antibiotik. Jakarta.

Kementerian Kesehatan Republik Indonesia. 2013. Riset Kesehatan Dasar (RISKESDAS) 2013. Jakarta.

Kementerian Kesehatan Republik Indonesia. 2013. Formularium Rumah Sakit. Jakarta.
Kementerian Kesehatan Republik Indonesia. 2014. Profil Data Kesehatan Indonesia. Jakarta. Hal: 147-148

Kemenkes, 2011. Buletin Jendela Data dan Infomasi Kesehatan: Situasi Diare di Indonesia, Vol.2, 1,6, Kementrian Kesehatan RI, Jakarta.

Longe, R.I, 2010, Diarrhea, Dalam Handbook of Nonprescription Drugs, 14th ed., 405-431, American Pharmacist Association, Washington D.C.

Longe, R.L., dan Di Piro, J.T,. 2010. Diarrhea and Constipation, in Di Piro, J.T., Talbert, R.L., Yee, G.C., Matsko, G.R., Well, B.G., Posey, L.M., (Eds), Pharmacotherapy, A Pathophystologic Approach, Sixth Ed, 680, Appleton \& Longe, Stanford, Connecticut.

Meila O. 2016. Analisis Hubungan Penggunaan Antibiotik dengan Lama Perawatan Pada Pasien Anak Diare Di RSUP Persahabatan. SOCIAL CLINICAL PHARMACY INDONESIA JUORNAL [Vol. 1, No 1, 2016. Jakarta: Universitas 17 Agustus 1945.

McMaster dan St Joseph's Healthcare. 2015. MacPeds PEDIATRIC HANDBOOK. Pediatric McMaster Hospital. 
Ngastiyah. (2014). Perawatan Anak Sakit (2 ed.). Jakarta: Buku Kedokteran.

Sugiyono, 2014, Metode Penelitian

Kuantitatif Kualitatif dan R\&D. Bandung: Alfabeta.

Sugiyono, 2016. Metode Penelitian Kuantitatif, Kualitatif, dan R\&D. Bandung: CV Alfabeta.

Sugiyono, 2017. Penelitian Kuantitatif, Kualitatif dan R\&D. Bandung: Alfabeta.

Siregar CJP, Amalia L. 2012. Farmasi Rumah Sakit Teori dan Penerapan. Jakarta: EGC.

Simadibrata K, D. 2014. Diare Akut, in Setiati, S. et al. (eds) Buku Ajar Ilmu Penyakit Dalam. VI. Jakarta: Interna Publishing, pp. 1899-908.

Tjay dan Rahardja, 2012, Obat-obat Penting, Khasiat, Penggunaan dan Efek Sampingnya, Edisi V, PT Elex Media Komputindo Kelompok Gramedia, Jakarta.

World Gastroenterology Organisation. 2011. Probiotics and Prebiotics. WGO Press.

World Gastroenterology Organisation Global Guidelines. 2012. Acute diarrhea in adults and children: a global perspective. WGO Press.
World Health Organization. 2015. Pocket book of hospital care for children, guidelines for the management of common illnesses with limited resources. Geneva: WHO Press. 77

World Health Organization (2010). Infant mortality. World Health Organization

Widjaja, M.C, 2015, Mengatasi Diare dan Keracunan Pada Balita, Cetakan 1, Kawan Pustaka, Jakarta

Widoyono, 2015. Penyakit Tropis, Epidemiologi, Penularan, Pe ncegahan, dan Pemberantasan. Jakarta: Erlangga. 